\title{
NUMERICAL TAXONOMY OF VIBRIONACEAE ISOLATED FROM BIVALVES AND FISHES IN VALPARAISO COASTS, CHILE
}

\author{
(Taxonomía numérica de Vibrionaceae aisladas desde bivalvos y peces \\ en zonas costeras de Valparaiso, Chile)
}

Bernardo Prado * 1, Claudia Becerra 1, María Isabel Vázquez 1, Ana del Moral 2, Eliana Sánchez 1 \& Miguel Zazópulos 1 1. Laboratory of Microbiology, Universidad Tćcnica Federico Santa María, Sede Viña del Mar, Chile. 2. Department of Microbiology, Faculty of Pharmacy, University of Granada, Granada, Spain.

Key words: Numerical taxonomy. Vibrionaceac, bivalies, fishes. Palabras clave: Taxonomía numćrica, Vi'bronaceae.bivalvos, peces.

\section{SUMMARY}

A taxonomic study has been carried out on 123 strains of the Vibrionaceae family isolated firom bivalves an fishes in Valparaiso coats. All strains were characterized with 86 phenotypic tests and clustering using $S_{\mathrm{S} I}$ coefficient and the UPCHA L linking analysis. The strains were chustered into three phena at a $80 \%$ similarity level. These strains were identified as Aeromonas hydrophila, Vibrio sp. and Plesiomonas shigelloides.

\section{INTRODUCTION}

Members of the Vibrionaccac family comprisc one of the predominant bacterial group in marine environment and constitute a considerable part of marine heterotrophic bacterial population (Kancko\& Colwcll 1973). Microorganisms which belong to Vibrionaccac family are ubiquitous in estuarine and marine waters and sediments Kaper et al. 1973). They are associated with nitrogen fixation (West ct al. 1985), degradation of spccificorganic pollutants (West and Colwell 1984) and colonization of surfaces and internal organs of invertcbrate and vertcbrate marinc animals (Huq ct al. 1983; Colwcll \& Grimes 1984; Pricur et al. 1990). Under stress conditions, some of the specics

\section{RESUMEN}

Se realizó un estudio taxonómico de 123 cepas de la familia I'ibronaceae aisladas desde bivalvos y peces en las costas de Valparaiso. Todas las cepas fueron caracterizadas con 86 test fenotipicos que se agruparon usando el coeficiente $S_{S M} y$ el análisis de union de UPCGM IA. Las especies fiueron agrupadas en tres fenones con un nivel de similitud del $80 \%$. Estas especies fueron identificadas como Acromonas hydrophila, Vibrio sp. y Plesiomonas shigelloides.

that are commensal to marine animal can behave as pathogens, causing severe cconomic loss for to the marine culture trade (Sindermann 1970).

In this paper we describe the phenotypic charactcristics of 123 strains of the Vibrionaceac family that were isolated from sca food in Valparaíso coasts, Chile, which are of great interest for the shellfish and fish commerce.

\section{MATERIAL AND METHODS}

\section{Samples.}

Withing June and Norember 1994, 10 samples of bivelves and fish were collected in the chilcan coastal area

* Correspondence to: Dr. Bernardo Prado A. Laboratory of Microbiology, Univcrsidad Técnica Fcderico Santa María, Sede Viña del Mar, Casilla 920. Viña del Mar, Chilc. 
comprising Calcta Membrillo (Valparaiso) and Con Con, V Región.

\section{Bacterial strains.}

The 123 strains were isolated from shellfish (Mesodesma donacium, Pyura chilensis and Ameghinomya anticua) and fish (Merluccius gayi). The isolates were obtained from enrichments in alkaline peptone water ( $\mathrm{pH} 8.6)$. followed by inoculation in agar TCBS (Difco) (APHA 1992). The following reference strains were included: Vibrio parahaemolyticus ATCC 17802, Vibrio fluvialis ATCC 33809, Vibrio costicola NCMB 701, Aeromonas hidrophyla ATCC 7966, Aeromonas caviae ATCC 15468 and Aeromonas sobria CIP 7433 .

The cultures were maintained on Tryptic Soy Agar (TSA) with $3 \% \mathrm{NaCl}$ at $30^{\circ} \mathrm{C}$.

\section{Characterization of the isolations.}

86 phenotypic characters including morphological, physiological, biochemical, nutritional tests and sensibility to the $0 / 129$ compound at a concentration of 10 or 15 (g. were determined for each strain on media containing $1 \% \mathrm{NaCl}$, and at an incubation temperature of $30^{\circ} \mathrm{C}$. Details of the procedures have been previously described (Veron 1975: Lee et al. 1979; Ventosa et al. 1982; Quesada et al. 1984; Wets \& Colweell 1984)

\section{Numerical analysis.}

A total of 48 characters were selected for numerical analysis. Positive and negative results were coded as 1 and 0 respectively; no comparable or missing data were coded as 9. Strain similarities were estimated with Simple Matching $\left(\mathrm{S}_{\mathrm{SM}}\right)$. (Sokal and Michener 1958) coefficient and clustering was achicved by the unweighted pair-group method of association (UPGMA) (Sneath \& Sokal 1973). The test error was estimated by examining 12 strains in duplicate (Sneath \& Johnson 1972). The computation was performed by the MINT program (Rohllf 1985).

\section{RESULTS AND DISCUSSION}

Each strain was cxamined for 86 characters. All strains were Gram-negative, motile, oxidase. catalase and nitrate reduction positive; and able to ferment glucose. They produced acid from ribose, glucose, trehalose, fructose, galactose. maltose and glicerol. utilized glucose as the sole carbon source and grew at $\mathrm{pH} 10$ and $37^{\circ} \mathrm{C}$

Negative characteristics for all strains were: $\mathrm{H} 2 \mathrm{~S}$ production, urease, phenylalanine deamination; acid from inulin, sorbose, xilose, adonitol and dulcitol; utilization of: malonate, L-lysine, L-methionine, L-valine, L-triptophan, L-phenylalanine, L-cystcine and adenine as the sole carbon source. Production of difusible pigment, swarming, luminiscence, growth in $10 \% \mathrm{NaCl}$ were not observed.

These characteristics were excluded from the final data matrix. since they were not differentiating value. Taxonomic resemblance among the 123 strains examined was accordingly based on 48 characters. The probability for test error was estimated to be $3,0 \%$ by the method of Sneath and Johnson (1972).

The results of numerical taxonomic analysis of all 123 strains, grouped by $S_{S M}$ coefficient and UPGMA clustering yielded the dendrogram shown in Fig. 1. The majority of the strains could be grouped into three phena at a $70 \%$ similarity level. Table 1 lists the main features of the tree phena. The Jaccard coefficient $\left(\mathrm{S}_{\mathrm{J}}\right)$ was also used. It gave a similar clustering pattern, but the clusters formed around a $55 \%$ similarity level.

Cophenetic correlation coefficient was 0.859 for

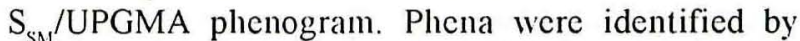
comparing properties of the strains with published diagnostic keys and tables.

Phenon A: the 32 strains of this phenon clustered at a $85 \%$ similarity level. They are isolated from fish and molluscs. This phenon has been identified as Acromonas hydrophila since includes the type strain $A$. hydrophila ATCC 7966 and the phenotipic characteristics of the microorganisms belonging to this group agrees with the description of this strain carricd out by Popoff (1984). However, there are some differences: esculine hydrolysis, acid production from salicine and Voges-Proskauer test, which are considered positive by Popoff (1984). Our results also agree with the description of $\boldsymbol{A}$. hydrophila reported by Austin et al. (1989).

Phenon B: At a similarity level of $82 \%$ most of strains (89) grouped in phenon B. Distinctive characters of the strains of marine Vibrio included in this group are: motile, oxidase-positive, a fermentative type of metabolism. sensibility to (0/129, $\mathrm{NaCl}$ requirements for growth, arginine dehidrolase negative and ornitine and lisine descarboxi-lase positive. These phenotipic characteristics agree with the description of genus Vibrio carried out by Bauman et al. (1984). All the strains included in this phenon were isolated from molluscs and seem to be very related with the marine environment and their fauna.

Phenon C: The three strains of phenon C grouped at a 93\% similarity level. The microorganisms included in this phenon are arginine, ornitine and lisine decarboxilase positive, they ferment the inositol and the lactose, they don't produce amilase, lipase, gelatinase. desoxorribo- 
Table 1. Phenotypic characteristic of Vibrionaceae strains.

\begin{tabular}{|c|c|c|c|}
\hline Phenon & $\mathbf{A}$ & B & $\mathrm{C}$ \\
\hline $\mathrm{N}^{\circ}$ of strains & 32 & 89 & 3 \\
\hline Arginine decarboxilase & 100 & 0 & 100 \\
\hline Lysine decarboxilase & 32 & 100 & 100 \\
\hline Ornithine decarboxilase & 0 & 100 & 100 \\
\hline Arginine dehydrolase & 100 & 0 & 100 \\
\hline Degradation of : Casein & 90) & 100 & () \\
\hline Tween 80 & 100 & 100 & 0 \\
\hline Aesculin & 4 & 0 & 0 \\
\hline Production of : Amylase & 100 & 100 & 0 \\
\hline Gelatinase & 100 & 100 & () \\
\hline Deoxyribonuclease & 100 & 100 & 0 \\
\hline Lecithinase & 100 & 100 & 0 \\
\hline Acid from: L- arabinose & 95 & 100 & 0 \\
\hline L- rhamnose & 4 & 100 & 0 \\
\hline D- cellobiose & 72 & 0 & 0 \\
\hline D- lactose & 73 & 0 & 100 \\
\hline Sucrose & 100 & 100 & 0 \\
\hline Inositol & 0 & (1) & 100 \\
\hline Manitol & 100 & 100 & 0 \\
\hline Sorbitol & 85 & 0 & 0 \\
\hline Salicine & 32 & 85 & 0 \\
\hline D- manose & 100 & 100 & 0 \\
\hline Haemolysis & 96 & 100 & 0 \\
\hline Indole & 93 & 95 & 100 \\
\hline Voges-Proskahuer & 32 & 0 & 0 \\
\hline Methyl red & 41 & 0 & 0 \\
\hline Gas glucose & 96 & () & 0 \\
\hline \multicolumn{4}{|l|}{ Utilization as sole carbon } \\
\hline L-arabinose & 95 & 100 & 0 \\
\hline D- cellobiose & 72 & () & () \\
\hline Galactose & 91 & 100 & 100 \\
\hline Succinate & 63 & 100 & 0 \\
\hline Gluconate & 94 & 100 & () \\
\hline Glysine & 16 & 100 & 0 \\
\hline Glutamate & 94 & 100 & 0 \\
\hline L- arginine & 97 & 100 & () \\
\hline L- histidine & 97 & 100 & 100 \\
\hline L- proline & 72 & 100 & 0 \\
\hline L- asparagine & 100 & 100 & 0 \\
\hline Aspartate & 50 & 100 & 0 \\
\hline L-serine & 100 & 100 & 0 \\
\hline L- threonine & 38 & 100 & 0 \\
\hline Ethanol & 0 & 88 & 0 \\
\hline Growth at: $4^{\circ} \mathrm{C}$ & 97 & 0 & 0 \\
\hline $45^{\circ} \mathrm{C}$ & 25 & 0 & 100 \\
\hline Growth in $\% \mathrm{NaCl}: 0$ & 100 & 0 & 100 \\
\hline 3 & 25 & 100 & 100 \\
\hline 6 & 0 & 100 & () \\
\hline 8 & () & 100 & 0 \\
\hline Susceptibility to & & & \\
\hline $0 / 129 \quad 150 \mathrm{ug}$ & 0 & 100 & 100 \\
\hline
\end{tabular}

Figure 1. Simplified dendrogram showing clustering of 123 strains of Vibrionaceae, based on the Simple Matching coefficient and unweinghted pair group method with averages (UPGMA) clustering.

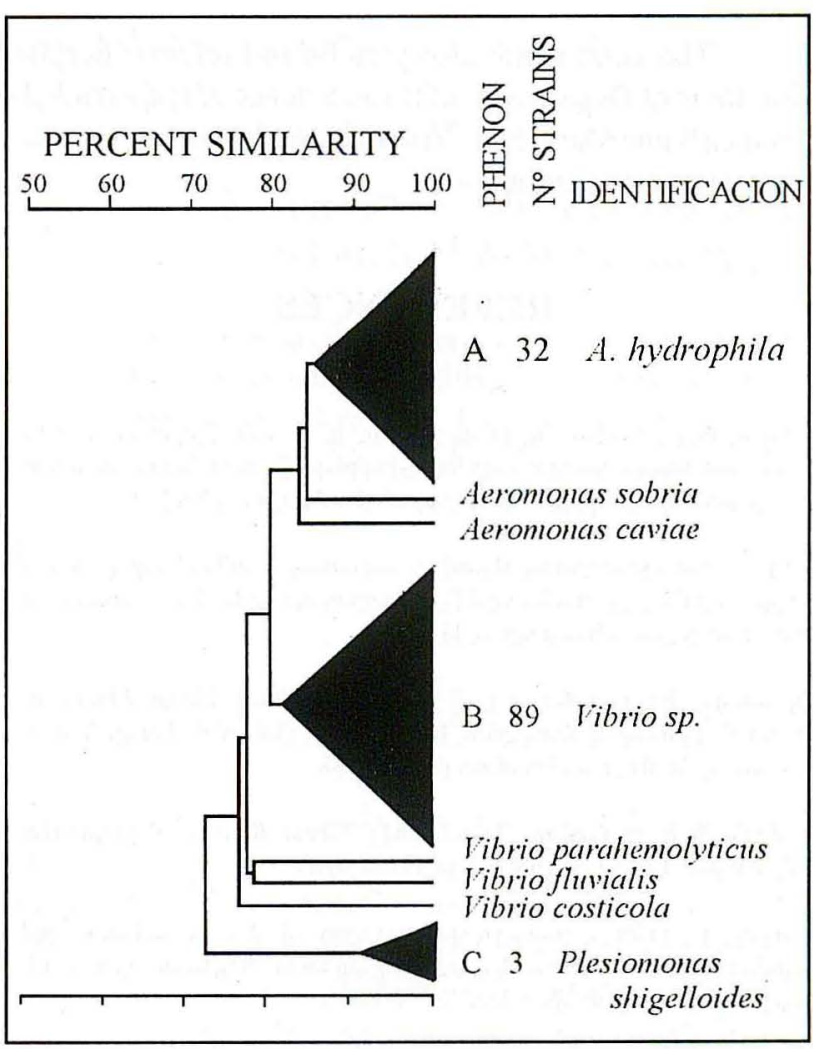

nuclease neither caseinase, they also utilize very few compounds like only source of carbon, nitrogen and energy. These characteristics are identical with the description of the genus Plesiomonas (Schubert, 1984).

The present taxonomic study of isolates from marine foods was focused to microorganisms of the Vibrionaceae family. The results on strains identification agrees with these carried out by other authors (Esteve,1995; Kaznowki et al. 1989; Austin et al. 1989; Ortigosa et al. 1989). Although our strains differ in some phenotipic characteristics from the reported by these authors. They are included within the genera Vibrio, Aeromonas and Plesiomonas.

Our study demonstrates that the genus Vibrio is the most abundant (89 strains) of the total of isolates studied (123). They constitute a very homogeneous group in their phenotipic characteristics and all of then have a specific requirement of $\mathrm{NaCl}$ for optimal growth.

The Vibrionaceac family is an habitual component in the microbiotc of bivalve molluscs and fish, and this is an important ecological niche for this family such as 
reported by other authors (Pricur et al. 1990); Ortigosa et al. 1989; West et al. 1986; Wong et al. 1992)

\section{ACKNOWLEDGEMENTS}

The authors are also grateful to Professor Sergio Karelovic of Department of Basic Science of Universidad Técnica Santa María Sede Viña del Mar. for their guidance. suggestions and comments.

\section{REFERENCES}

Austin, D.A.; McIntosh, D. \& Austin, B. (1989). Taxonomy of lihs associated Aeromonas spp., with the description of Aeromonas salmonicida subsp. smithia subsp. nov. Syst. Appl. Microbiol. 11: 277-290

APIIA . American Public IIealth Association. (1992). Compendium of Methos for the Microbiologyeal Examination of Foods. (Eds. Vanderzand and Splittstoesser) W'ashington, D.C.

Baumann, P.; Furniss, A.l. \& Lee, J.V. (1984). Genus Vïbrio. In Bergay's Manual of Systematic Bacteriology: (Ed. N.R. Krieg) Vol. 1, Baltimore: William and Wilkins.pp. 518-538

Colwell, R.R. \& Grimes, D..J. (1984). Tïbrio diseases of marine fish populations. Helgol. Meeresunters 37: 265-287

Esteve, C. (1995). Numerical Taxonomy of Acromonadaceac and Vibrionaceae associated with reared fish and surrouding fresh and brackish water. System. Appl. Microbiol. 18: 391-402

Huq, A.; Small, E.B.; West, P.A.; Huq, M.I.; Ralmman, R. \& Colwell, R.R. (1983). Ecological relationships between I Z̈brio cholerae and planktonic crustacean copepods. Appl. Environ. Microbiol. 45: 275-283

Kaneko, T. \& Colwell, R.R. (1973). Ecology of I ïbrioparahaemolyticus in Chesapeake Bay. J. Bacteriol. 113: -24-32

Kaper, J.B.; Locman, H.; Remmer, E.F.; Kristensen, K. \& Colwell, R.R. (1983). Numerical taxonomy of vibrios isolated fron estuerine enviromments. Int. J. Syst. Bacteriol. 33: 229-255

Kaznowski, A.; Wlodarczak, K. \& Paetz, H. (1989). A numerical taxonomy of Vibrionaceae isolated from water, Sewage. water-oil emulsion and fishes. Syst. Appl. Microbiol. 12: 172-178

Lee, J. \& Donovan, T, J. (1985). I Zibrio, Aeromonas and Plesiomonas. In. Isolation and identification of microrganisms of medical and veterinary importance. (Eds. Collins and Change) Society for Applied Bacteriology, Tenchnical series n ${ }^{\circ}$ 21, Academic Press. London. pp. 13-33

Ortigosa, M.; Esteve, C.. \& Pujalde, M. (1989). I Z̈brio specie in sea water and mussels: abundance and numerieal taxonomy. Syst. Appl. Microbiol. 12: 316-325

Popoff, M. (1984). Genus Aeromonas. In Bergey's Manual of Systematic Bacteriology, Vol. 1, (Ed. N.R. Krieg) Baltimore: William and Wilkins. pp. 545-548.

Prieur, D.; Mevel, G.; Nicolas, J.L.; Plusquelec, A . \& Vigneulle, M. (1990). Interaction from bivalves mollusc and bacterias in marine enviromment. Ocenogr. Mar. Biol. Ann. Rev. 28: 277-352

Quesada, E.; Ventosa, A.; Ruiz-Berraquero, F. \& Ramos-Cormenzana, A. (1984). Deleya halophila, a new species of moderately halophilic bacteria. Int. J. Syst. Bacteriol. 34: 287-292

Rohlf, F.J. (1985). Numerical taxonony system of multivariate statistical programs. Stony Brook NY. State University of New York.

Schubert, R.K.W. (1984). Genus Plesiomonas. In Bergey's Manual of Systematic Bacteriology, Vol. 1. N.R. Krieg (Ed.) Baltimore: William and Wilkins. pp. 548-550

Sindermamn, C..J. (1970). Principal diseases of marine fish and shell fish. Academic Press. INC... New York.

Sokal, R.R. \& Nichener, C.I). (1958). A statistical method for evaluating systematic relationships. Univ: of Kansas. Sci. Bull. 38: 1409-1438

Sneatl, P.II.A. \& Sokal, R.R. (1973). Numerical Taxonomy. The Principles and Practice of Numerical Taxonomy. San Francisco, W.H. Freeman.

\& Johnson, R. (1972). The influence on numerical taxonomic similarities of errors in microbiological test. J. Gen. Microbiol. 72: $377-392$

Veron, M. (1975). Nutrition et tasonomic des Eternobacteriaceae et bacteries voisines. I. Methods d'etude des auxanogrammes. Ann. Microbiol. Int. Pals. 126 A:267-274

Ventosa, A.; Quesada, E.; Rodriguez-Valera, F.; Ruíz-Berraquero, F. \& Ramos-Cormenzana, A. (1982). Numerical taxonomy of moderately halophilic Gram-negative rods. I.Gen. Microbiol. 128: 1959-1968

West, P.A.; Brayton, P.R.; Bryant, T.N. \& Colwell, R.R. (1986). Numerical tasonomy of Vibrios isolated from acuatic environment. Int. J. Syst. Bacteriol. 36: 531-543

\& Colwell, R. R. (1984). Identification and classification of Vibrionaceale and overview, In R.R. Colwell (ed.). Vibrios in the environment. John Wiley and Sons, New York. pp. 285-363

; Brayton, P.R.; Twilley, R.R.; Bryant, T.N. \& Colwell, R.R. (1985). Numerical taxonomy of nitrogen-lixing " decarboxylase-negative" I Zibrio species isolated from aquatie environments. Int. J. Syst. Bacteriol. 35: $198-205$

Wong, II. C.; Ting S.II. \& Shich, W.R. (1992). Incidence of toxigenic vibrios in foods available in Taiwan. J. Appl. Bacteriol. 73: 197-202 